\title{
Settings of Organizational Adjustments due to Digital Servitization
}

\author{
David Jaspert \\ Ruhr-Universität Bochum \\ david.jaspert@isse.rub.de
}

\author{
Martin Ebel \\ Ruhr-Universität Bochum \\ martin.ebel@isse.rub.de
}

\begin{abstract}
Recent studies indicate that companies in manufacturing should adapt their organizational structures in the course of digital servitization in order to successfully innovate and offer smart services. However, although we are amid the transformation, driven by digitization and service orientation, there seems to be a lack of information that explicitly supports the adaption of the organizational structures of manufacturing firms. Thus, this paper deals with the impact of smart service innovation on organizational structures by examining 13 German manufacturing companies. By means of a qualitative template analysis various changes within the organizational structure could be detected. Those findings were summarized to five different settings of adjustments in the organizational structure of the examined corporations. These shall serve as a guide for practitioners but also broaden scientific understanding of organizational change in the context of digital servitization.
\end{abstract}

\section{Introduction}

Fast-moving competitive environments require continuous adaptation and, when necessary, a complete redesign of what a company does to maintain engagement with its ecosystem [1]. Such a competitive environment is found, for example, in product-oriented industries such as mechanical engineering in Germany. Differentiation in the market and enhanced competitiveness through pure product innovation is becoming increasingly difficult to achieve. Thus, to meet ever-changing conditions and respond to increasing competition, manufacturing companies have begun developing and expanding services to give their previously product-focused businesses a novel competitive edge [2]. Strategically pursued, the above-described phenomenon was termed servitization [3]. Like in many other industries, digitalization is also transforming the manufacturing industry [4]. This is also impacting servitization. Acting as the driver and enabler of servitization $[5,6]$, digitalization allows companies to develop digitally enhanced smart services. Those kind of services are described as "digital, data-based service, building up on some kind of product as a data provider" [7] and are characterized by innovative business models and enhanced value to the customer $[6,8,9]$. Along with the development of smart services goes the transformation of companies' processes, capabilities, and strategies, a progression which is described with the term digital servitization [10-12]. However, companies, especially in traditional industries such as mechanical engineering, tend to struggle with this transformation $[12,13]$. Thus, research is focused on better understanding behaviors within these transformations and providing assistance and guidance to practitioners to successfully transform their businesses. with the transformation. Many contributions concentrate on smart service design [14], smart service engineering, the development of the technical and digital infrastructure of smart service systems [15] or smart service innovation (SSI) [16]. The latter term will be used for the further course of this paper when referring to companies' efforts to put smart services into practice.

The ability to change organizational design plays a decisive role in transformation of manufacturing firms and has already been highlighted in previous research [17-19]. A key resource here is the organizational structure [20]. For instance, studies suggest that manufacturers striving for servitization, must adapt their organization to meet the new demands that arise $[19,21,22]$. They stress the importance of effectively adapting organizational structures or, if necessary, completely restructuring.

Like in servitization efforts, the new smart service business models and the resulting digital servitization of firms often puts stress on a company's existing organizational structure [23]. However, only a few notable research papers have addressed this transformational necessity [24-26].

For example, contributions on the effects of digital servitization on intraorganizational relationships [27], interorganizational organizational roles [16] or the 
effect of digital servitization on the degree of centralization and integration of organizational structures [26] have been researched. However, none goes into a detailed examination of industrial companies and which adjustments they have made to their organizational structure during their transformation toward becoming a supplier of smart services.

Thus, to provide guidance on this highly relevant matter, we pose the following research questions:

(1) How have German manufacturing companies adjusted their organizational structure for SSI?

(2) What guidance can be given to other companies to adjust their organizational structure for digital servitization?

The remainder of the paper is structured as follows. Section 2 provides theoretical input on digital servitization and organizational structure. In section 3, we describe the methodology we followed. Section 4, presents the results of our qualitative study. In Section 5 , we discuss the findings.

\section{Related works}

\subsection{Digital servitization}

Many companies are trying to exploit the benefits of integrating digital technologies into their "products, business processes, sales channels, and supply chains." [28] In mechanical engineering, for instance, companies are integrating technologies like the internet of things (IOT), Cloud Computing, Sensors, etc. $[8,29]$ leading to end-to-end connections of physical assets and new digital ecosystems [30, 31]. This is affecting the strategy, organization, and the business model of named companies, a process which is described by the term digital transformation [32].

At the same time a service transformation in manufacturing has taken place. Known as servitization it reflects on the transition from product- to serviceoriented businesses [3, 17] Resulting product service systems (PSS) can improve a firm's operational and environmental performance and lead to competitive advantages [33]. Thus, companies striving to additionally offer services have been transforming themselves.

Some research papers point out that digitalization acts as a driver and enabler of servitization [6,34]. The increasing integration of digital technologies into the innovation of services or PSS is associated with the term digital servitization $[12,35]$. It can be seen as an intersection of the described digital and service transformation with its own transformational effects $[5,36]$. Through digital servitization manufacturing companies react in order to develop new kinds of smart services to add to their products and traditional services [8, 34]. Smart services work through connected devices which integrate physical and digital competencies in a complex socio-technical service system [15].

Overall, digital servitization is characterized by closer supplier-customer relationships. Aspects like co-creation, long-term engagement, and greater investment in the relationship are consequences which have intra- and inter-organizational effects [11]. Adjustments of as well as the internal processes [13, 37], and also collaborations across organizational boundaries, are required for SSI and smart service sales [38].

Under the described circumstances, digital servitization refers to the overall transformational process companies are going through when changing their product-centric business models to a (smart) service-centric business logic enabled by digital technologies $[35,36]$. The focus of this work shall be on changes within organizational structures.

\subsection{Organizational structure}

Transferred to the industrial context, the concept of organization stands for a system in which employees and machines divide work among themselves as a means of achieving the company's goals in the most efficient manner [39].

Making changes to organizational design is a common strategy of companies aiming to remain competitive and effective [40,41]. Besides specific capabilities or employee selection, the organizational structure represents a central component of the organizational design [42, 43]. As per SigGelKow [44], the organizational structure has to fit and at the same time be flexible enough to cope with the conditions under which the company operates. Overall, many different opinions on and definitions of organizational structure exist [45].

In general, the definitions characterize organizational structure around the dimensions of centralization, formalization, and integration [46]. Centralization describes the point at which decisions are made within the organization. Formalization refers to the extent to which a company adheres to structures, rules, and procedures. Integration describes the degree of coordination of labor and tasks. These dimensions have been applied to different models from research and practice (e.g. McKinsey's Seven-S [47] and Mintzberg's Pentagon [40]). In addition, dimensions such as specialization and hierarchy can be found in other recent studies of organizational structure [48, 49]. Specialization refers to which extent labor is distributed within an organization. The hierarchy 
dimension describes the external form of the organizational structure, commonly recorded in an organigram.

There are different ways to structure an organization. The structure depends on the extent to which an above-described dimension shall be focused [50]. Structures can be linear, functional, matrix, organic, divisional, or based around work teams, among other models. The matrix structure is predominantly used by large companies that operate internationally [51]. It combines the benefits of the functional and multidivisional structures [52]. For our purpose we will use a simplified form of the matrix structure [53] (Figure 1). The structure has a superordinate strategic level. Business areas (BA) which depending on the size of the company can be equated with business units (BU) or include BU are positioned below. Within the $\mathrm{BA} / \mathrm{BU}$ a crossfunctional structure of departments and products with a management level in each is placed. With this structure employees from different departments can be set together in cross-functional teams.

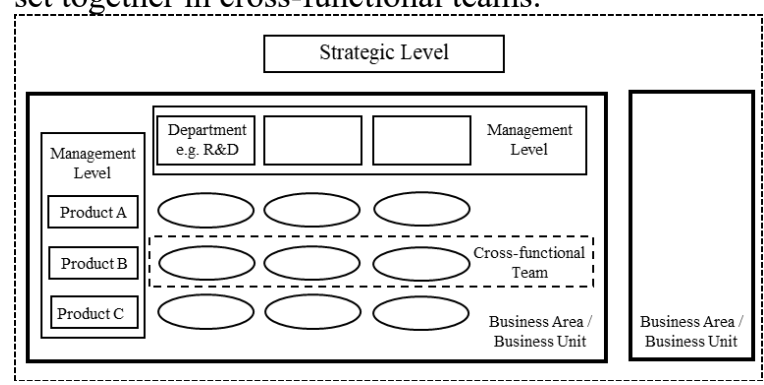

\section{Figure 1. Cross-functional matrix used for the} further course of this work

Organizational research has shown that various factors, such as company growth, technological progress, changing customer expectations, or competitive situations have an impact on organizational design and thus on organizational structure [45].

Digital servitization represents a novel influencing factor for the organizational design [17, 23, 27]. Especially for manufacturers, this process entails consequences and challenges [43]. An examination of the influence of digital servitization on the organizational structure in the manufacturing context is therefore required $[17,54,55]$.

\subsection{Change of organizational structure in manufacturing}

The challenges of transformation can be seen in different dimensions. One of these dimensions is the adaptation and change of the organization's structure
[28]. To this end, research has already been published on the impact of servitization and digital servitization on the organizational structure $[21,25,35,56]$. In the context of digital servitization KOLDEWEY ET AL. [26], for instance, analyze different structural changes and highlight the key strategic decisions of choosing between separation (e.g. spin-off as stand-alone units) and integration (e.g. departments interwoven into the existing structure), and between centralization and decentralization. The aspect of centralization can similarly be found in studies on servitization [21] before digital technologies accelerated this transformation even further [57]. SKLYAR ET AL. [35] look at this phenomenon from an ecosystem perspective and find that companies going through digital servitization are seeking to integrate responsibilities (e.g., moving away from a separation of product and service) and centralize capabilities (e.g., central IT support). At the same time, in the course of digital servitization and SSI companies are willing to open up more and cooperate with actors outside of their corporation [16].

The changing ecosystem perspective seems to be appropriate since emerging smart product service systems are often very complex and only occur through the cooperation and collaboration of multiple actors [16].

However, despite the growing research interest in digital servitization and its impact on organizational structure, explicit changes within the organizational structures of manufacturing companies appear to be largely unexplored $[8,25]$.

\section{Methodology}

The intention of this study is to examine changes to organizational structure in the course of digital servitization using the example of German mechanical engineering companies. To do so we decided to use a qualitative research approach because it provides room for discovery [58] and is suitable for exploratory research [59]. We chose to follow the systematic process of template analysis for data collection and analysis [60]. This approach combines inductive and deductive data analysis. It lies between the top-down (e.g. matrix analysis [61]) and the bottom-up approaches, such as grounded theory [62] of thematic analysis, and seemed appropriate to addressing our research questions. Our research procedure is shown in figure 2. There are a number of different methods for collecting data. Based on the specific research interest, we decided to conduct expert interviews. This frequently used method seeks to reveal a special body of knowledge through the individual views of a special 




Figure 2. Template analysis procedure

target group of interviewees. People are considered experts when they have knowledge of issues related to their professional role and can thus deliver competent and reliable data [63]. We established the range of experts in accordance with the objectives of this study. Consequently, we focused on employees from large German mechanical engineering firms that transform their portfolio and already add smart services.

We looked for respondents with appropriate knowledge and insight into potential organizational changes which had evolved through SSI. As a result, we decided to question people with management-level responsibility or those directly underneath them. In total, the co-expert author team conducted 17 interviews in 13 different companies between October 2019 and August 2020 (Table 1).

We used a semi-structured interview script with open-ended questions to guide each interview. Each interview lasted between 40 and 89 minutes and concentrated on three main aspects relevant to this research. First, we gathered personal information about the interviewee. Second, we assessed their basic understanding of smart services as well as the company's digital servitization efforts in the development and marketing of smart services. Here the innovation of at least one smart service was decisive. We did not further attach importance in a differentiation between the smart services for this work. Third, we focused on changes within the organizational structure which can be linked to the companies' digital servitization activities. Each respondent was interviewed once. We conducted three interviews in person and fourteen by telephone or video call. Table 1 gives an overview of the questioned expert, their position in the company, its size, and the duration of each interview. After data collection, we transcribed the 17 interviews and made ourselves familiar with the data we had gathered [64]. Subsequently, we transferred the transcripts into the MAXQDA qualitative analysis software and carried out a preliminary inductive structural coding [65] and a deductive a-priori theme coding starting with five interviews [60]. We used results from previous research on reorganizational changes as a priori theme. Using focused coding [66] as a second cycle coding method, we clustered codes with a shared meaning to

Table 1. Overview of expert interviews

\begin{tabular}{|c|c|c|c|c|c|}
\hline No. & Company & Industry & Employees & Duration & Experts Position \\
\hline 1 & A & Propulsion & $1000-5000$ & $70: 53 \mathrm{~min}$ & Head of Digital Business \\
\hline 2 & B & Forming & $5000-10.000$ & $57: 48 \mathrm{~min}$ & Director After Sales \\
\hline 3 & C & Logistics & $1000-5000$ & $59: 41 \mathrm{~min}$ & Businessowner Digital Business \\
\hline 4 & D & Automation & $>10.000$ & $68: 36 \mathrm{~min}$ & Agile Coach \\
\hline 5 & D & Automation & $>10.000$ & $58: 30 \mathrm{~min}$ & Head of Sales \\
\hline 6 & E & Automation & $>50.000$ & $89: 06 \mathrm{~min}$ & Head of Business Unit Energy \\
\hline 7 & E & Automation & $>50.000$ & $63: 40 \mathrm{~min}$ & Head of Sales \\
\hline 8 & F & Pumping & $5000-10.000$ & $40: 27 \mathrm{~min}$ & Head of Software as a Service und Digital Services \\
\hline 9 & G & Automotive & $>50.000$ & $57: 42 \mathrm{~min}$ & Head of Innovation Portfolio \\
\hline 10 & G & Automotive & $>50.000$ & $66: 40 \mathrm{~min}$ & Head of Sales \\
\hline 11 & H & Pumping & $>10.000$ & $64: 59 \mathrm{~min}$ & Head of Product Management Digital Solutions \\
\hline 12 & H & Pumping & $>10.000$ & $54: 52 \mathrm{~min}$ & Head of Product Management \\
\hline 13 & I & Conveying & $500-1000$ & $59: 46 \mathrm{~min}$ & Team leader Innovation \\
\hline 14 & J & Automation & $<5000$ & $50: 14 \mathrm{~min}$ & Assistant to the Chairman of the Board \\
\hline 15 & K & Materials & $>10.000$ & $44: 17 \mathrm{~min}$ & Senior Director Strategy \& Transformation Management \\
\hline 16 & L & Automation & $>10.000$ & $51: 40 \mathrm{~min}$ & \\
\hline 17 & M & Machining & $>10.000$ & $48: 00 \mathrm{~min}$ & \\
\hline
\end{tabular}


themes and developed an initial template of changes within the organizational structure. By applying this template to seven further transcripts, we noticed that we had to modify the initial template by adding, summarizing, or deleting certain codes. After doing so, we used the modified template to code the remaining five interviews. At this point no substantial modifications were made. This indicated data saturation [62] and we closed the third round of coding with a final template. Further, we used the template of gained top-level and lower-level themes to interpret the data. This led to different settings of adjustments in the organizational structures of the analyzed companies.

\section{Results}

Our results indicate that changes within the organizational structure of mechanical engineering companies in the course of digital servitization have already taken place and are currently being implemented. At the same time, all participating company representatives noted that their firms were still in the early stages of SSI and making the corresponding organizational adjustments. As respondent H said: "We are still in our infancy when it comes to smart services and the associated adjustments. But it is growing massively." Some also expressed doubts: "We don't yet know exactly at what speed and in what dimension this will continue." (Company E); [...] ]everything is new, no one knows exactly how it works and for the organization of course completely new anyway." (Company D)

An overall result from the inquiry was that no company differentiates between SSI for internal or external purposes. Consequently, the indicated structural changes were made regardless the recipient of the innovated smart service.

However, the interviewees acknowledge that external influences such as competitors or customer inquiries in recent years have made the companies realize the need engage in the field of innovative smart services. An important finding was that they felt their existing processes and structures were inadequate for developing and marketing smart service offerings. As one interviewee explained: "There is, of course, a growing realization that such services do not fall from the tree, but that you need an infrastructure for them and the infrastructure also needs to be developed."

Many said that their first reaction was to adjust their processes. Structural changes followed or were applied simultaneously. It became apparent that the companies are currently at different stages in their SSI efforts. While company D, for example, is still relatively new in this area ("We have not yet reached the point where we can say that we are already in the scaling phase"), other companies have already been dealing with smart services for several years (e.g. company M). This difference impacts organizational adjustments, and the responses varied accordingly. While some companies have undertaken broader changes, others have only implemented small adjustments. It must be noted, that all interviewees reported that their companies were organized in a matrix structure and that up to now this overall structure has not been affected by digital servitization. Further, we can state that there does not seem to be a universal approach to changing the organizational structure. Rather, companies are making a wide variety of adjustments to enable the most efficient, smooth SSI and marketing for their purposes.

However, the data also indicated that adjustments have been made at three different levels of the organizations. We found adjustments at the organizational level, department level, and employee level. Table 2 shows the top-level themes of organizational structural changes with their associated lower-level themes.

We were able to report three adjustments at the department level (DL1-DL3). DL1 covers the creation of new departments on the strategic level globally responsible for SSI. DL 2 includes the introduction of new functional departments for SSI and SSI support activities within BA. An example for this is company $\mathrm{G}$, which created a department for SSI and at the same time set up a separate department for data analysis and data security which can help with SSI if needed. In the lower-level theme DL3 we grouped companies whose adjustments were made through changes to existing departments. These departments were part of the tradi-

Table 2. Final template of organizational adjustments and related settings

\begin{tabular}{|c|c|c|c|c|c|c|c|c|}
\hline \multirow{3}{*}{$\begin{array}{c}\begin{array}{c}\text { Top-Level } \\
\text { Themes }\end{array} \\
\begin{array}{c}\text { Lower-Level } \\
\text { Themes }\end{array} \\
\end{array}$} & \multicolumn{3}{|c|}{$\begin{array}{c}\text { Adjustment } \\
\text { at Department Level }\end{array}$} & \multicolumn{3}{|c|}{$\begin{array}{c}\text { Adjustment at } \\
\text { Employee Level }\end{array}$} & \multicolumn{2}{|c|}{$\begin{array}{c}\text { Adjustment at } \\
\text { Organizational Level }\end{array}$} \\
\hline & \multicolumn{2}{|c|}{ New Department } & \multirow{2}{*}{$\begin{array}{l}\text { Change of } \\
\text { Department } \\
\text { (DL3) }\end{array}$} & \multicolumn{3}{|c|}{ New and changed Positions } & \multirow{2}{*}{$\begin{array}{c}\text { New separate BA } \\
\text { Organization } \\
(\mathrm{OL} 1)\end{array}$} & \multirow{2}{*}{$\begin{array}{c}\text { External } \\
\text { Collaboration } \\
\text { (OL2) }\end{array}$} \\
\hline & $\begin{array}{l}\text { Global } \\
\text { (DL1) }\end{array}$ & $\begin{array}{l}\text { In BA } \\
\text { (DL2) }\end{array}$ & & $\begin{array}{l}\text { Board } \\
\text { (EL1) }\end{array}$ & $\begin{array}{c}\text { Management } \\
(\text { EL2) }\end{array}$ & $\begin{array}{c}\text { Operational } \\
\text { (EL3) }\end{array}$ & & \\
\hline Setting 1 & $\mathrm{x}$ & & & $\mathrm{x}$ & & & & \\
\hline Setting 2 & & & $\mathrm{x}$ & & & $\mathrm{x}$ & & \\
\hline Setting 3 & & $\mathrm{x}$ & & & $\mathrm{x}$ & & & \\
\hline Setting 4 & & & & & & & $\mathrm{x}$ & \\
\hline Setting 5 & & & & & & & & $\mathrm{x}$ \\
\hline
\end{tabular}


tional organizational structure but have been redesigned due to digital servitization. At the employee level, we differentiate between the shifting or creation of new responsibilities on the board, management or operational levels. EL1 refers to changes or the creation of new positions on the Executive Board, EL2 to adjustments to functions on the management level. Also, we found new or changed job profiles and positions within the department teams which we assigned to EL3. On the organizational level we grouped the creation of a parallel BA (OL1) and any kind of collaboration with external partners (OL2) for SSI purposes. We did so because different queried representatives indicated that the companies' SSI activities depend on external assistance, and these new processes can have effects on the organizational structure.

As a final step of our template analysis we closely examined the presented adjustments and were able to identify five different settings of changes within the examined organizations. In the following we will describe those in more detail using the figure of a matrix structure and providing examples for each of the lower-level adjustments we observed.

\subsection{Setting 1: Adjustment on strategic level}

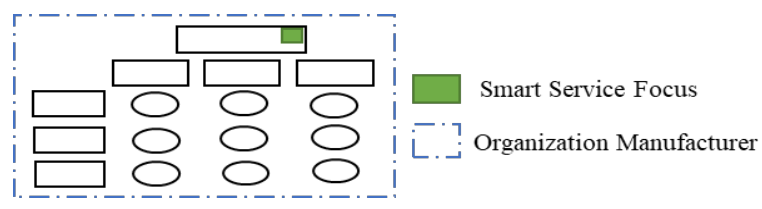

Figure 3. Setting 1 in matrix structure

In this setting, companies adjust on DL1 and/or EL1. The idea of these adjustments is to centralize decisions concerning SSI at a high level and follow a top-down approach. Companies, for instance, introduce new strategic positions with responsibility for their smart service offerings. An interviewee from Company G explained: "So the Board of Management has now brought in someone who is responsible for that, so to speak, but that is directly under Board of Management." Other companies expanded the areas of responsibility of current board members. In this context, for instance, the respondent from company $\mathrm{J}$ said: "The Chief Digital Officer component has been added to the Chief Technology Officer terrain." In both cases, an awareness of the topic of smart service is generated on the EL1. The representatives of companies $\mathrm{A}$ and $\mathrm{M}$ described the introduction of a new department (DL1) which is "not linked to the region. This is an autonomous central unit." Company $\mathrm{G}$ goes in a similar direction and has created "an independent profit-center globally responsible for digital solutions."

\subsection{Setting 2: Adjustments in existing operational level}

These adjustments focus for example on the integration of new responsibilities in existing teams (EL3) with a focus on SSI. This applied to company E, which defined employees in all departments "who have a greater affinity in that area and are given the task: How can I optimize the processes and offerings in the area in which I'm working by using new digital methods? And so, we want to anchor the topic of digital solutions even more firmly in the organization."

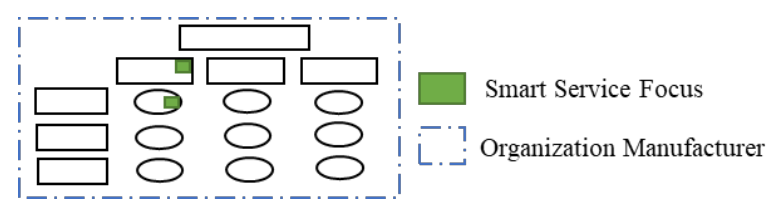

Figure 4. Setting 2 in matrix structure

Different companies have installed their own Smart Service salespeople in the sales department. Other firms reconfigured their IT or traditional R\&D departments for SSI tasks and so have adjusted building groups within departments (DL3). For instance, company $\mathrm{H}$ "has massively expanded the IT security topic and bundled data protection and IT security in an own subteam".

\subsection{Setting 3: New department and management level positions}

Companies following this pattern undertake changes in DL2 and EL2. They create at least one new department with responsibilities for SSI. In doing so, they also introduce a new management position at the head of the new department which can oversee different teams. For company B, it is clear that they "must have a unit that takes care of such products, service is also a product."

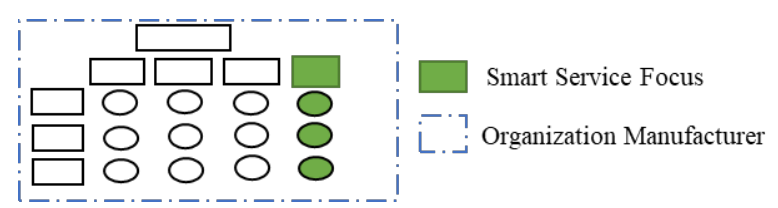

Figure 5. Setting 3 in matrix structure

Company $\mathrm{G}$, for instance, has decided in the course of this "to set up a dedicated sales department for us in Industry 4.0, so to speak, for the time being." Many companies create their own department or even 
business area for SSI. Interviewee from company $\mathrm{J}$ described: "we have a third business area where the main activities for smart services of this kind are to be found.". Many interviewees indicated a different way of working within these new SSI units. Hierarchies are flatter, and project teams work in an agile way to develop smart services. The representative from company D said: "We don't have a hierarchy inside this unit $[. .$.$] that is, that is the organization of how we$ now work together in these agile teams."

\subsection{Setting 4: Separate SSI organization}

The goal of this adjustment is to create a parallel organization that works independently on SSI (change in OL1). An independent organization for SSI can either arise from within the own traditional organization (business unit) or be acquired and integrated into the overall company structure. In both cases the parallel organization works on SSI and supports the already existing traditional business.

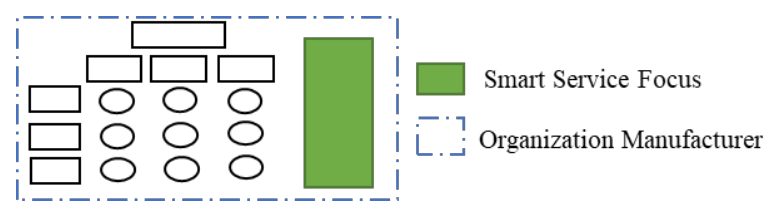

Figure 6. Setting 4 in matrix structure

Company L for example "made a strategic move by taking over one hundred percent of a start-up and then merged a business unit with it that had previously been part of our core business". In contrast, company $\mathrm{H}$ founded a separate unit for SSI with 10-15 people, who also work outside the factory premises. This has an impact on the traditional organization. "The core organization has not been touched so far, but the smart services run alongside the core organization."

\subsection{Setting 5: Collaboration with partners}

"I think it's enormously important that you don't do everything yourself." That is how the respondent from company $\mathrm{C}$ introduced his company's frequent interactions with other partners during SSI. Just like this, other companies adjust through changes in OL2.

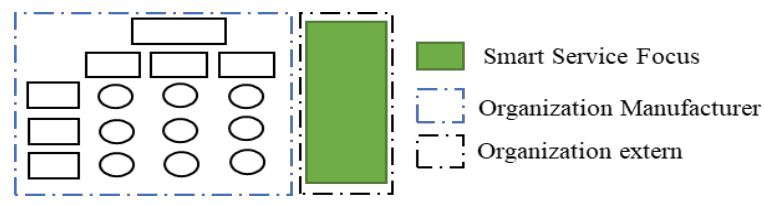

Figure 7. Setting 5 in matrix structure

Companies consciously use this setting in combination with other settings and collaborate with partners who provide services, hardware, or software which support their SSI. Named partners are either institutions of higher education with a special competence in areas that are profitable for SSI or business enterprises. Concerning agreements with universities, an interviewee from company $\mathrm{C}$ explained: "If we are missing a 3D print part or if we are missing a developer or if we need a workshop on this or any topic or a UX designer, whatever, then we can basically call up this service there as a service via a token system, which is part of our framework agreement with the university." In the case of the companies brought in, size is irrelevant. The decisive factor is what the external partner can deliver. Company E, for example, works with startups because they have a certain "flexibility, spatial proximity and also lower barriers in terms of working hours and the like." Company G acquires "many software components because it doesn't make sense to develop them ourselves." Company E "works in a very diversified way with a wide variety of service providers, because we say we have to be able to use the digital know-how, but not develop everything ourselves."

\section{Discussion}

Similar to servitization which leads to changes in organizational structure of companies [67], the results from this study show that digital servitization and an increasing smart service focus are influencing the organizational structures of large German manufacturing companies. This goes in line with the observation made by Hess [28], who, in their transformation framework, noticed that changes in value creation and the use of new technologies go hand-in-hand with structural changes of organizations.

We argue that changes in the organizational structure can be differentiated on three different levels, (1) organizational, (2) departmental, (3) employee. This differentiation supports earlier findings on structural changes of manufacturing companies [25].

The final template and the various sub-themes of structural changes were used to derive five adjustment settings of organizational structuring. They shall serve to increase comprehensibility and provide an adaptable overview. While changes to the settings can occur individually, most of the interviewed company employees indicated that their organization combines different settings to cope with digital servitization. Company A, for instance, has made changes on the highest strategic level (setting 1), restructured their sales department by implementing smart service specialists (setting 2, implemented a new business unit for smart service development in the traditional structure (C), and collaborates with a subsidiary within 
its own organizational structure when it comes to SSI matters (setting 4).

Within setting 3, we see a tendency in many companies to create departments with a particular focus on SSI, which work together with departments of the traditional structure. In this regard, the formation of project teams with low or no hierarchical stipulation is often cited. In contrast to HESS ET AL. [68], who concluded that "it has not been clear whether separation or integration (of structures for new digital activities) is the preferred," this study indicates a tendency towards integration (13 out of 13 companies). At the same time, it bolsters the findings of research that suggest or identify the formation of separate units for SSI activities [19, 69, 70]. The changes in this setting also support the view of WOLF [71], who sees a shift from hierarchy to holacracy in SSI.

We could also find companies that try building up a separate organization for SSI activities within their own structures (setting 4). They willingly separate the traditional from the smart service business. That means they build a parallel business area for SSI or SSI supporting tasks but integrate them into the existing structures. Expanding on KOLDEWEY ET. AL [26] we claim that the individual settings also provide information about the degree of organizational integration and centralization for the smart service business. Setting 2 can be viewed as a rather decentralized change. In contrast, settings 1,3 , and 4 point to a higher degree of centralization of SSI decisions in a top-down or separate and specialized process. Companies which integrate the smart service business and its activities into existing departments and structures apply to setting 1 when changing the strategic employee level or setting 2. Whereas firms which build new units and organizations or collaborate with external partners (settings 1 if a new global department for SSI is created, 3, 4 and 5) separate smart service activities through their changes to the organizational structures.

Our findings are in line with recent studies that show that companies are adapting their organizational structures in the course of digital service transformation [72]. Established companies that traditionally operate in silos and reflect a mentality based on hierarchy and authority are trying to change [72]. It becomes clear that organizations are becoming more open to collaboration [35, 72]. Interviewees mentioned an increase in both internal as well as external cooperation for SSI. Nevertheless, it is also evident that the companies often operate closely to their core businesses. This is also in line with existing findings that engineering-driven mentalities in particular find it difficult to adopt a stronger customer and solution orientation, and to change the entire business model [12]. A finding whether this is good or bad cannot be made here yet. But especially in times of disruptive change, it might be helpful to break completely new ground in certain areas [73].

As practical implications, we argue that the identified adjustment settings can be used by all manufacturing companies regardless the size or already realized structural changes in the course of digital servitization. Latter companies can use the five settings and the template for comparison purposes to possibly integrate further adjustments. For companies who have not yet started reorganizing their structure, this probably applies to small and middle seized companies, the settings and the detailed changes shall serve as inspiration to initiate reorganizing their structure. Here we recommend starting the structural adjustments on the strategic level and combining those with changes from other settings over time.

Furthermore, this study also has theoretical implications because it takes a very detailed look at the process of reorganization, which has not been done so far for digital servitization [24]. We helped to show how organizational changes occur [17] and expanded the research on how digital servitization affects organizations $[35,72]$.

As with any research, this study comes with some limitations that invite further research. The first is the limited number of interviewed companies. The changes within their structures and the derived settings probably do not represent a holistic view on the tackled research topic. Thus, the number of examined companies could be expanded in future qualitative or quantitative studies. This could serve for validation purposes of the proposed settings. A second limitation is that no differentiation between different smart services and ways of SSI was made. Further research could pick this up and for instance try to give a more detailed differentiation between SSI for internal and external purposes with their effect on the organizational structure. Finally, we acknowledge that our research is limited to big German companies. We encourage fellow researchers to further investigate and validate our results with small and middle-sized companies and corporations in other countries.

Acknowledgments This contribution is part of the project "Smart Service Retrofits for the Highest Availability of Machinery and Equipment" (retrosmart) funded by the German Federal Ministry of Education and Research (grant number: 02K16C000).

\section{References}

[1] Teece, D.J., "Dynamic Capabilities: Routines versus Entrepreneurial Action", Journal of Management Studies, 49(8), 2012, pp. 1395-1401. 
[2] Kowalkowski, C., H. Gebauer, B. Kamp, and G. Parry, "Servitization and deservitization: Overview, concepts, and definitions", Industrial Marketing Management, 60, 2017, pp. 4-10.

[3] Vandermerwe, S. and J. Rada, "Servitization of business: Adding value by adding services", European Management Journal, 6(4), 1988, pp. 314-324.

[4] Kohtamäki, M., V. Parida, P.C. Patel, and H. Gebauer, "The relationship between digitalization and servitization: The role of servitization in capturing the financial potential of digitalization", Technological Forecasting and Social Change, 151, 2020, p. 119804.

[5] Coreynen, W., P. Matthyssens, and W. van Bockhaven, "Boosting servitization through digitization: Pathways and dynamic resource configurations for manufacturers", Industrial Marketing Management, 60, 2017, pp. 42-53.

[6] Parida, V., D. Sjödin, and W. Reim, "Reviewing Literature on Digitalization, Business Model Innovation, and Sustainable Industry: Past Achievements and Future Promises", Sustainability, 11(2), 2019, p. 391.

[7] Koldewey, C., J. Gausemeier, R. Dumitrescu, H.H. Evers, M. Frank, and J. Reinhold, "Development Process for Smart Service Strategies: Grasping the Potentials of Digitalization for Servitization", in Digitalization: Approaches, Case Studies, and Tools for Strategy, Transformation and Implementation, D.R.A. Schallmo and J. Tidd, Editors. 2021. Springer International

[8] Ardolino, M., M. Rapaccini, N. Saccani, P. Gaiardelli, G. Crespi, and C. Ruggeri, "The role of digital technologies for the service transformation of industrial companies", International Journal of Production Research, 56(6), 2018, pp. 2116-2132.

[9] Frank, A.G., G.H. Mendes, N.F. Ayala, and A. Ghezzi, "Servitization and Industry 4.0 convergence in the digital transformation of product firms: A business model innovation perspective", Technological Forecasting and Social Change, 141, 2019, pp. 341-351.

[10] Vendrell-Herrero, F., O.F. Bustinza, G. Parry, and N. Georgantzis, "Servitization, digitization and supply chain interdependency", Industrial Marketing Management, 60, 2017, pp. 69-81.

[11] Kamalaldin, A., L. Linde, D. Sjödin, and V. Parida, "Transforming provider-customer relationships in digital servitization: A relational view on digitalization", Industrial Marketing Management, 89, 2020, pp. 306-325.

[12] Sjödin, D., V. Parida, M. Kohtamäki, and J. Wincent, "An agile co-creation process for digital servitization: A microservice innovation approach", Journal of Business Research, 112, 2020, pp. 478-491.

[13] Lütjen, H., F. Tietze, and C. Schultz, "Service transitions of product-centric firms: An explorative study of service transition stages and barriers in Germany's energy market", International Journal of Production Economics, 192, 2017, pp. 106-119.

[14] Dreyer, S., D. Olivotti, B. Lebek, and M.H. Breitner, "Focusing the customer through smart services: a literature review", Electronic Markets, 29(1), 2019, pp. 55-78.

[15] Beverungen, D., M. Matzner, and C. Janiesch, "Information systems for smart services", Information Systems and e-Business Management, 15(4), 2017

[16] Anke, J., J. Poeppelbuss, and R. Alt, "It Takes More than Two to Tango: Identifying Roles and Patterns in MultiActor Smart Service Innovation", Schmalenbach Business Review, 72(4), 2020, pp. 599-634.
[17] Baines, T., A. Ziaee Bigdeli, R. Sousa, and A. Schroeder, "Framing the servitization transformation process: A model to understand and facilitate the servitization journey", International Journal of Production Economics, 221, 2020, p. 107463.

[18] Kanninen, T., E. Penttinen, M. Tinnilä, and K. Kaario, "Exploring the dynamic capabilities required for servitization", Business Process Management Journal, 23(2), 2017, pp. 226-247.

[19] Porter, M.E. and J.E. Heppelmann, "How Smart, Connected Products Are Transforming Companies", Harvard Business Review (114), 2015, pp. 96-112.

[20] Huikkola, T., M. Kohtamäki, and R. Rabetino, "Resource Realignment in Servitization", Research Technology Management, 59, 2016, pp. 30-39.

[21] Gebauer, H. and C. Kowalkowski, "Customer-focused and service-focused orientation in organizational structures", Journal of Business and Industrial Marketing, 2012, pp. 527-537.

[22] Ahmady, G.A., M. Mehrpour, and A. Nikooravesh, "Organizational Structure", Procedia - Social and Behavioral Sciences, 230, 2016, pp. 455-462.

[23] Klein, M.M., S.S. Biehl, and T. Friedli, "Barriers to smart services for manufacturing companies - an exploratory study in the capital goods industry", Journal of Business \& Industrial Marketing, 33(6), 2018, pp. 846-856.

[24] Baines, T., A. Ziaee Bigdeli, O.F. Bustinza, V.G. Shi, J. Baldwin, and K. Ridgway, "Servitization: revisiting the state-of-the-art and research priorities", International Journal of Operations \& Production Management, 37(2), 2017, pp. 256-278.

[25] Jaspert, D. and J. Dohms, "Reorganization of Manufacturing Companies through Digital Servitization: A Systematic Review", AMCIS 2020 Proceedings, 2020.

[26] Koldewey, C., J. Gausemeier, N. Chohan, M. Frank, J. Reinhold, and R. Dumitrescu, "Aligning Strategy and Structure for Smart Service Businesses in Manufacturing", in 2020 IEEE International Conference.

[27] Bustinza, O.F., E. Gomes, F. Vendrell-Herrero, and S.Y. Tarba, "An organizational change framework for digital servitization: Evidence from the Veneto region", Strategic Change, 27(2), 2018, pp. 111-119.

[28] Matt, C., T. Hess, and A. Benlian, "Digital Transformation Strategies", Business \& Information Systems Engineering, 57(5), 2015, pp. 339-343.

[29] Suppatvech, C., J. Godsell, and S. Day, "The roles of internet of things technology in enabling servitized business models: A systematic literature review", Industrial Marketing Management, 82, 2019, pp. 70-86.

[30] Reis, J., M. Amorim, N. Melão, and P. Matos, "Digital Transformation: A Literature Review and Guidelines for Future Research", in Trends and Advances in Information Systems and Technologies, Á. Rocha, H. Adeli, L.P. Reis, and S. Costanzo, Editors. 2018. Springer International Publishing: Cham.

[31] Lee, M., Y.-C. Lee, and C.J. Chou, "Essential Implications of the Digital Transformation in Industry 4.0", Journal of Scientific \& Industrial Research, 76, 2017, pp. 465-467.

[32] Agarwal, R., G. Gao, C. DesRoches, and A.K. Jha, "Research Commentary - The Digital Transformation of Healthcare: Current Status and the Road Ahead", Information Systems Research, 21(4), 2010, pp. 796-809.

[33] Paschou, T., M. Rapaccini, F. Adrodegari, and N. Saccani, "Digital servitization in manufacturing: A systematic 
literature review and research agenda", Industrial Marketing Management, 89, 2020, pp. 278-292.

[34] Kohtamäki, M., V. Parida, P. Oghazi, H. Gebauer, and T. Baines, "Digital servitization business models in ecosystems: A theory of the firm", Journal of Business Research, 104, 2019, pp. 380-392.

[35] Sklyar, A., C. Kowalkowski, B. Tronvoll, and D. Sörhammar, "Organizing for digital servitization: A service ecosystem perspective", Journal of Business Research, 104, 2019, pp. 450-460.

[36] Lerch, C. and M. Gotsch, "Digitalized Product-Service Systems in Manufacturing Firms: A Case Study Analysis", Research-Technology Management, 58(5), 2015, pp. 45 ff.

[37] Bustinza, O.F., A.Z. Bigdeli, T. Baines, and C. Elliot, "Servitization and Competitive Advantage: The Importance of Organizational Structure and Value Chain Position", Research-Technology Management, 58(5), 2015, pp. 53-60.

[38] Anke, J., J. Poeppelbuss, and R. Alt, "Joining Forces: Understanding Organizational Roles in Interorganizational Smart Service Systems Engineering", 15th International Conference on Wirtschaftsinformatik, 2020

[39] Pirntke, G., Moderne Organisationslehre: Aktuelle Konzepte und Instrumente; mit Aufgaben und Lösungen, expert-Verl., Renningen, 2007.

[40] Mintzberg, H., "The Structuring of Organizations", in Readings in Strategic Management, D. Asch and C. Bowman, Editors. 1989. Macmillan Education, London.

[41] Kindström, D. and C. Kowalkowski, "Service innovation in product-centric firms: a multidimensional business model perspective", Journal of Business \& Industrial Marketing, 29(2), 2014, pp. 96-111.

[42] Král, P. and V. Králová, "Approaches to changing organizational structure: The effect of drivers and communication", Journal of Business Research, 69(11), 2016, pp. 5169-5174.

[43] Galbraith, J.R., "Organizing to Deliver Solutions", Organizational Dynamics, 31(2), 2002, pp. 194-207.

[44] Siggelkow, N. and J.W. Rivkin, "Speed and Search: Designing Organizations for Turbulence and Complexity", Organization science, 16(2), 2005, pp. 101-122.

[45] Tran, Q. and Y. Tian, "Organizational Structure: Influencing Factors and Impact on a Firm", American Journal of Industrial and Business Management, 03(02), 2013, pp. 229-236.

[46] Galbraith, J.R., Organization design, 2nd edn., AddisonWesley, 1978

[47] Waterman, R.H., T.J. Peters, and J.R. Phillips, "Structure is not organization", Business Horizons, 23(3), 1980, pp. $14-26$.

[48] Kieser, A. and P. Walgenbach, Organisation, 6th edn., Schäffer-Poeschel Verlag, Stuttgart [Germany], 2013.

[49] Robbins, S.P., D.A. DeCenzo, and P. Mascaro Sacristán, Fundamentos de administración: Conceptos esenciales y aplicaciones, 8th edn., Pearson Educación, México, 2009.

[50] Robbins, S.P. and T. Judge, Essentials of organizational behavior, 12th edn., Pearson, Boston, 2014.

[51] Bergmann, Organisation und Projektmanagement, Springer Berlin Heidelberg, Berlin, Heidelberg, 2016.

[52] Miles, R.E., C.C. Snow, O.D. Fjeldstad, G. Miles, Lettl, and C, "Designing Organizations to Meet 21st-Century Opportunities and Challenges", Organizational Dynamics, 39(2), 2010, pp. 93-103.

[53] Stuckenbruck, L.C., "The matrix organization", Project Management Quarterly (10(3)), 1979, pp. 21-33.
[54] Wuenderlich, N.V., K. Heinonen, A.L. Ostrom, L. Patricio, R. Sousa, C. Voss, and J.G. Lemmink, "Futurizing" smart service: implications for service researchers and managers", Journal of Services Marketing, 29(6/7), 2015, pp. 442-447.

[55] Bilgeri, D., F. Wortmann, and E. Fleisch, How Digital Transformation Affects Large Manufacturing Companies' Organization, ICIS Proceedings, 2017.

[56] Schüritz, R., S. Seebacher, G. Satzger, and L. Schwarz, Datatization as the Next Frontier of Servitization Understanding the Challenges for Transforming Organizations, ICIS Proceedings, 2017

[57] Coreynen, W., J. Vanderstraeten, A. van Witteloostuijn, N. Cannaerts, E. Loots, and H. Slabbinck, "What drives product-service integration? An abductive study of decision-makers' motives and value strategies", Journal of Business Research, 117, 2020, pp. 189-200.

[58] Williams, C., "Research Methods", Journal of Business \& Economics Research (JBER), 5(3), 2011.

[59] Creswell, J.W., W.E. Hanson, V.L. Clark Plano, and A. Morales, "Qualitative Research Designs", The Counseling Psychologist, 35(2), 2007, pp. 236-264.

[60] King, N., J. Brooks, and S. Tabari, "Template Analysis in Business and Management Research", in Qualitative Methodologies in Organization Studies, M. Ciesielska and D. Jemielniak, Editors. 2018. Springer International

[61] Maxwell, J., "Qualitative Research Design : An Interactive Approach / J.A. Maxwell", 2012.

[62] Corbin, J.M. and A. Strauss, "Grounded theory research: Procedures, canons, and evaluative criteria", Qualitative Sociology, 13(1), 1990, pp. 3-21.

[63] Dorussen, H., H. Lenz, and S. Blavoukos, "Assessing the Reliability and Validity of Expert Interviews", European Union Politics, 6(3), 2005, pp. 315-337.

[64] King, N. and J.M. Brooks, Template analysis: For business and management students, Sage, Los Angeles, 2017.

[65] Saldaña, J., The coding manual for qualitative researchers, 3rd edn., Sage, 2016.

[66] Charmaz, K., A pratical guide through qualitative analysis, Sage, London, 2006.

[67] Perona, M., N. Saccani, and A. Bacchetti, "Research vs. Practice on Manufacturing Firms' Servitization Strategies: A Gap Analysis and Research Agenda", Systems, 5(1), 2017, p. 19

[68] Hess, T., C. Matt, A. Benlian, and F. Wiesböck, Options for Formulating a Digital Transformation Strategy, MIS Quarterly Executive, 15(2), 2016.

[69] Alghisi, A. and N. Saccani, "Internal and external alignment in the servitization journey - overcoming the challenges", Production Planning \& Control, 26(14-15), 2015, pp. 1219-1232.

[70] Lachiewicz, S., M. Matejun, P. Pietras, and M. Szczepańczyk, "Servitization as a Concept for Managing the Development of Small and Medium-sized Enterprises", Management, 22(2), 2018, pp. 80-94.

[71] Wolf, V., "Understanding Smart Service Systems Transformation - A Socio-Technical Perspective", ECIS 2020 Research-in-Progress Papers. 30., 2020.

[72] Tronvoll, B., A. Sklyar, D. Sörhammar, and C. Kowalkowski, "Transformational shifts through digital servitization", Industrial Marketing Management, 89, 2020, pp. 293-305.

[73] Johnson, M.W., C.M. Christensen, and H. Kagermann, "Reinventing your business model", HBR, (Vol. 86), 2008, pp. $50-59$. 